\title{
Soil organic carbon pool changes following land-use conversions
}

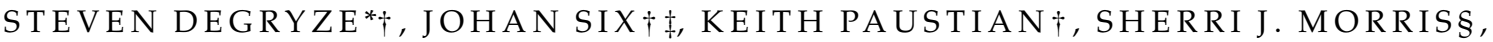 \\ ELDOR A. PAUL† and ROEL MERCKX* \\ *Laboratory for Soil and Water Management, K.U. Leuven, Kasteelpark Arenberg 20, 3001 Heverlee, Belgium, †Natural Resource \\ Ecology Laboratory, Colorado State University, Fort Collins, CO 80523, USA, †Department of Agronomy and Range Science. \\ University of California, Davis, CA 95616, USA, §Department of Biology, Bradley University, Peoria, IL 61625, USA
}

\begin{abstract}
Carbon (C) can be sequestered in the mineral soil after the conversion of intensively cropped agricultural fields to more extensive land uses such as afforested and natural succession ecosystems. Three land-use treatments from the long-term ecological research site at Kellogg biological station in Michigan were compared with a nearby deciduous forest. Treatments included a conventionally tilled cropland, a former cropland afforested with poplar for 10 years and an old field (10 years) succession. We used soil aggregate and soil organic matter fractionation techniques to isolate $C$ pools that (1) have a high potential for $C$ storage and (2) accumulate $C$ at a fast rate during afforestation or succession. These fractions could serve as sensitive indicators for the total change in $C$ content due to land-use changes. At the mineral soil surface $(0-7 \mathrm{~cm})$, afforesting significantly increased soil aggregation to levels similar to native forest. However, surface soil $(0-7 \mathrm{~cm}) \mathrm{C}$ did not follow this trend: soil $C$ of the native forest site $\left(22.9 \mathrm{tCha}^{-1}\right)$ was still significantly greater than the afforested $\left(12.6 \mathrm{tCha}^{-1}\right)$ and succession $\left(15.4 \mathrm{tCha}^{-1}\right)$ treatments. However, when the $0-50 \mathrm{~cm}$ soil layer was considered, no differences in total soil $\mathrm{C}$ were observed between the cropland and the poplar afforested system, while the successional system increased total soil $\mathrm{C}(0-50 \mathrm{~cm})$ at a rate of $0.786 \mathrm{tCha}^{-1} \mathrm{yr}^{-1}$. Afforested soils sequestered $\mathrm{C}$ mainly in the fine intraaggregate particulate organic matter (POM) $(53-250 \mu \mathrm{m})$, whereas the successional soils sequestered $C$ preferentially in the mineral-associated organic matter and fine intraaggregate POM C pools.
\end{abstract}

Nomenclature

$$
\begin{aligned}
\mathrm{POM} & =\text { particulate organic matter, i.e. organic matter of size }>53 \mu \mathrm{m} \\
\text { intra-POM } & =\mathrm{POM} \text { material contained within an aggregate } \\
\text { fine intra-POM } & =\text { intra-POM of size } 53-250 \mu \mathrm{m} \\
\text { coarse intra-POM } & =\text { intra-POM of size } 250-2000 \mu \mathrm{m} \\
\text { total light POM } & =\mathrm{POM} \text { material having a density }<1.85 \mathrm{~g} \mathrm{~cm}^{-3} \\
\text { total heavy POM } & =\mathrm{POM} \text { material having a density }>1.85 \mathrm{~g} \mathrm{~cm}^{-3} \\
\text { free light POM } & =\mathrm{POM} \text { not contained in a soil aggregate having a density }<1.85 \mathrm{~g} \mathrm{~cm}^{-3} \\
\text { mineral-associated } \mathrm{OM} & =\text { carbon associated with the silt and clay fraction }(<53 \mu \mathrm{m}) \\
\mathrm{MWD} & =\text { mean weight diameter, the estimated median size of all soil aggregates } \\
\mathrm{O} M & =\text { organic matter } \\
\text { macroaggregate } & =\text { aggregate of size }>250 \mu \mathrm{m} \\
\text { large macroaggregate } & =\text { aggregate of size }>2000 \mu \mathrm{m} \\
\text { small macroaggregate } & =\text { aggregate of size } 250-2000 \mu \mathrm{m} \\
\text { microaggregate } & =\text { aggregate of size } 53-250 \mu \mathrm{m} \\
\text { silt and clay } & =\text { soil fraction of size }<53 \mu \mathrm{m} .
\end{aligned}
$$

Correspondence: Steven De Gryze, tel. + 32 16329676,

fax + 32 16321997, e-mail: steven.degryze@agr.kuleuven.ac.be 
Keywords: afforesting, aggregate stability, carbon sequestration, intra-aggregate carbon, mineralassociated carbon, particulate organic matter

Received 23 December 2002; revised version received 20 August 2003; accepted 24 December 2003

\section{Introduction}

During the past two centuries, land-use practices such as deforestation and tillage have resulted in a net loss of soil carbon (C) to the atmosphere. Recent concerns about rising carbon dioxide $\left(\mathrm{CO}_{2}\right)$ concentrations in the atmosphere have focused attention on the possibility of sequestering $\mathrm{C}$ back into the soil system. This may be achieved by means of afforesting and other land-use conversions. It has been noted that these $\mathrm{C}$ sinks represent only a partial solution given that the capacity of soils to store carbon is finite (Hassink, 1996; Six et al., $2002 b)$ and that increases in soil organic matter (SOM) can be reversed if proper management is not maintained (Paustian et al., 2000). Nevertheless, soil C sequestration could be important in providing a mechanism to temporarily buffer rising atmospheric $\mathrm{CO}_{2}$ concentrations.

Carbon stored in forest ecosystems represents a substantial part of the global C stock. Worldwide, forests contain $\sim 70 \%$ of all plant $\mathrm{C}$ and $\sim 20 \%$ of all soil C. Furthermore, the average $C$ content of forest soils is relatively large: $120 \mathrm{tC} \mathrm{ha}^{-1}$ vs. a mean value of all ecosystem soils of $79 \mathrm{tC} \mathrm{ha}^{-1}$ (Amthor, 1998). The C content of forest soils, however, varies greatly with climatic and soil properties. Post et al. (1982) reported that forests in cooler climates often contain nearly twice as much soil $\mathrm{C}$ as warm temperate forests.

Many studies show large losses of soil $\mathrm{C}$ after forest clearing. For example, Ellert \& Gregorich (1996) estimated that $30-35 \%$ of C originally present in the A and $\mathrm{B}$ horizons of native temperate forest soils was lost after 30 or more years of cultivation. On the other hand, these large losses of soil $\mathrm{C}$ after forest clearing suggest that forest regrowth could lead to $C$ sequestration. Therefore, agriculture to forest conversions after 1950 were hypothesized to be a 'missing sink' in the global C cycle (Johnson \& Sharpe, 1983). Estimates of this sink ranged from 0.6 to $2.3 \mathrm{GtC} \mathrm{yr}^{-1}$ during the 1980s and from 2 to $4 \mathrm{GtC} \mathrm{yr}^{-1}$ during the 1990s (Schimel et al., 2001). However, Post \& Kwon (2000) estimated that only $5-10 \%$ of the inferred terrestrial sink could be explained by soil $\mathrm{C}$ accumulations during forest growth. Most likely, the missing sink is a combination of smaller sinks, such as $\mathrm{C}$ uptake by forests, and also by peatlands or wetlands combined with a higher ocean uptake than previously estimated (Schindler, 1999). This debate illustrates that significant uncertainties remain regarding the role of forests in the global $\mathrm{C}$ cycle and the environmental response to rising concentrations of atmospheric $\mathrm{CO}_{2}$ (Schimel et al., 2001).

Recent studies about the potential and rate of $\mathrm{C}$ sequestration in forests were reviewed by Rollinger et al. (1997) and Post \& Kwon (2000). The latter authors found an average rate of soil $\mathrm{C}$ accumulation after afforesting of $0.338 \mathrm{tC} \mathrm{ha}^{-1} \mathrm{yr}^{-1}$ although values vary greatly among studies. Jenkinson (1971) found an increase of $0.596 \mathrm{tCha}^{-1} \mathrm{yr}^{-1}$ after conversion of an old field to an oak forest while Robertson \& Vitousek (1981) reported a value of only $0.094 \mathrm{tC} \mathrm{ha}^{-1} \mathrm{yr}^{-1}$ for the same vegetation conversion type. The source of this variation is only partly understood.

In general, mechanistic $C$ sequestration studies can be divided into two groups: (1) studies that correlate total SOM accumulation with ecosystem driving variables (e.g. soil texture, soil structure, annual rainfall, temperature) and (2) studies that compare organic matter $(\mathrm{OM})$ fractions among treatments. Fractionation of OM implies the separation of the total $\mathrm{OM}$ into different parts that are thought to be functionally homogeneous with respect to physicochemical properties and turnover rate. The separation can be carried out by physical or chemical means: e.g. sieving, flotation, dispersion. The difference in $\mathrm{C}$ content between fractions of an agricultural field and the corresponding native vegetation can yield information about the mechanisms of $C$ sequestration (Six et al., 2002a; Del Galdo et al., 2003). Furthermore, fractions that are more sensitive to land-use changes than the total $C$ can serve as an early indicator of changes (Six et al., 2002a).

We followed the second approach and used two different fractionation schemes: (1) a complex fractionation combining sieving, dispersion and flotation steps and (2) a particulate organic matter (POM) fractionation with subsequent flotation (at $1.85 \mathrm{~g} \mathrm{~cm}^{-3}$ ) to separate light and heavy POM. The objectives of this study were to (1) investigate potential $C$ sequestration and the rate at which $\mathrm{C}$ accumulates in the mineral soil of afforested and successional plots, and (2) isolate fractions that have a high potential for $\mathrm{C}$ storage and that accumulate $\mathrm{C}$ at a fast rate.

\section{Materials and methods}

\section{Site description}

Michigan State University's W.K. Kellogg biological station is located in southwest Michigan $\left(42^{\circ} 24^{\prime} \mathrm{N}\right.$, 
$85^{\circ} 24^{\prime} \mathrm{W}$ ) at an elevation of $288 \mathrm{~m}$. Annual rainfall averages $890 \mathrm{~mm} \mathrm{yr}^{-1}$ (half as snow and half as rain). Potential evapotranspiration exceeds precipitation for approximately 4 months. Mean annual temperature is $9.7^{\circ} \mathrm{C}$. The soil is a Kalamazoo loam: fine-loamy, mixed, semiactive, mesic Typic Hapludalf. A soil horizon description is given in Table 1 .

In April and May 1999, we sampled the native deciduous forest and three treatments from the ongoing long-term ecological research experiment (LTER). This is a randomized complete block design with six replicate blocks and seven treatments. Before establishment of the LTER experiment in 1989, the site has been in agriculture for at least 100 years. Sampled treatments were: conventionally tilled cropland rotation (soybean, Glycine max L.; wheat, Triticum aestivum L. and corn, Zea mays L.), a cropland afforested with a fast growing Poplar, Populus clone, a natural succession managed by occasional burning or felling of woody biomass, and a native oak-hickory deciduous forest (Quercus sp.-Carya sp.). Before establishment of treatments, all plots were under the same corn-soybean rotation, except the sixth replicate plot, which was under alfalfa, Medicago sativa L. Mean aboveground primary production for the treatments were: $9.24 \pm 1.41 \mathrm{Mtha}^{-1} \mathrm{yr}^{-1}$ for the agricultural, $10.17 \pm 4.00 \mathrm{Mtha}^{-1} \mathrm{yr}^{-1}$ for the afforested and $4.24 \pm 0.37 \mathrm{Mtha}^{-1} \mathrm{yr}^{-1}$ for the successional treatment (Robertson et al., 2000). Sampling of the mineral soil was done in three layers $(0-7,7-25$ and $25-50 \mathrm{~cm})$. The complete experimental design is explained in http:// lter.kbs.msu.edu/experimentalDesign.html. Further biological, physical and agronomical background information can be found at http://lter.kbs.msu.edu/Data.

Six subsamples were taken from the mineral soil with a $6.7 \mathrm{~cm}$ diameter core from each replicate plot. Samples were taken at three points along the plot diagonal. At each point, two samples were taken approximately $60 \mathrm{~cm}$ apart. In the native forest, three trees were randomly selected and samples were taken at the base of the tree and $60 \mathrm{~cm}$ away from the tree. A subsample of each core was dried at the standard temperature of
$110{ }^{\circ} \mathrm{C}$ to determine gravimetric water content (Jarrell et al., 1999). Bulk density was determined for each sample by dividing soil core volume by dry soil weight. All samples were passed through an $8 \mathrm{~mm}$ sieve by gently crumbling the moist soil. The six samples were composited per plot and depth. Subsamples of $\sim 150 \mathrm{~g}$ were put into paper bags, allowed to dry at room temperature before samples were taken for analysis of total $\mathrm{C}$ and $\mathrm{N}$ and fractionations.

\section{Aggregate separation}

The complete fractionation sequence is illustrated in Fig. 1. Aggregates were separated by wet sieving as described by Elliott (1986). Prior to sieving, the soil $(100 \mathrm{~g})$ was submerged for $5 \mathrm{~min}$ in deionized water. Four aggregate fractions were obtained: $>2000 \mu \mathrm{m}$ (large macroaggregates), 250-2000 $\mu \mathrm{m}$ (small macroaggregates), $53-250 \mu \mathrm{m}$ (microaggregates) and $<53 \mu \mathrm{m}$ (silt and clay fraction). All fractions were oven dried overnight $\left(60^{\circ} \mathrm{C}\right)$ and stored in closed glass jars at room temperature. Fraction weights were corrected for different sand contents before comparison. The mean weight diameter (MWD), which is an approximation of the median size of the aggregates, was calculated as:

$$
\begin{aligned}
\text { MWD }= & \frac{2000+8000}{2}[A]+\frac{2000+250}{2}[B] \\
& +\frac{250+53}{2}[C]+\frac{53}{2}[D],
\end{aligned}
$$

where MWD is the mean weight diameter in $\mu \mathrm{m},[A]$, $[B],[C]$ and $[D]$ are weight percentages of the aggregate fractions and the silt and clay particles, respectively.

\section{Fractionation scheme A: separation of free light POM and intra-aggregate $P O M$}

Aggregates from the $0-7$ and $7-25 \mathrm{~cm}$ depths were analyzed for free light POM and intra-aggregate POM (intra-POM) using the method from Six et al. (1998). Soil taken from the $25-50 \mathrm{~cm}$ soil layer had too little

Table 1 Mineral soil horizon description of Kalamazoo soil

\begin{tabular}{lllcrrr}
\hline Horizon & Depth $(\mathrm{cm})$ & Texture & CEC $\left(\mathrm{cmol}_{\mathrm{c}} \mathrm{kg}^{-1}\right)$ & Total C $\left(\mathrm{g} \mathrm{kg}^{-1}\right)$ & $\left.\mathrm{Total} \mathrm{N}_{(\mathrm{kg}}{ }^{-1}\right)$ & $\mathrm{pH}$ \\
\hline Ap & $0-30$ & Loam & 8.4 & 12.85 & 1.31 & 5.5 \\
E & $30-41$ & Loam & 11.5 & 3.25 & 0.53 & 5.7 \\
Bt1 & $41-69$ & Silty clay loam & 15.3 & 2.25 & 0.42 & 5.3 \\
2Bt2 & $69-88$ & Silty loam & 4.1 & 0.67 & 5.42 \\
2E/Bt & $88-152$ & Silt & 2.3 & 0.20 & 0.18 & 5.6 \\
\hline
\end{tabular}

Adapted from the Kellogg Biological Station data catalog (Crum \& Collins, 1992). No error data were available. CEC, Cation Exchange Capacity. 
Fractionation scheme A

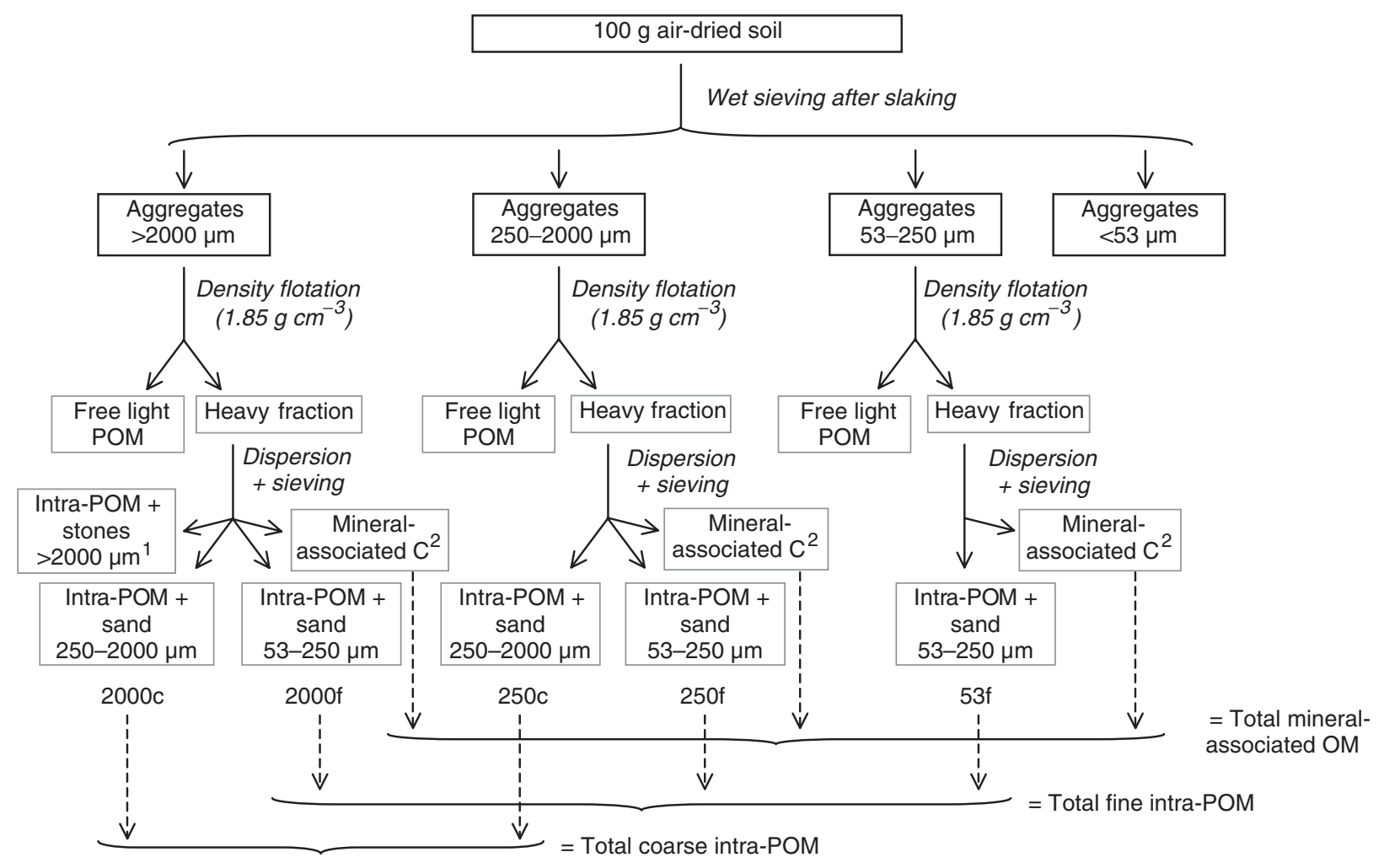

Fractionation scheme B

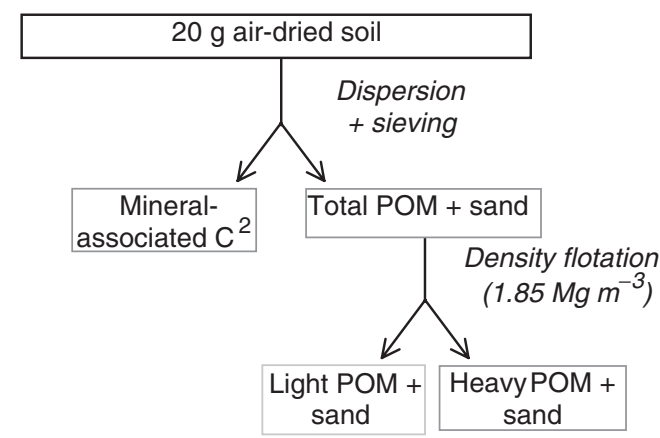

\footnotetext{
${ }^{1}$ This material was not further analyzed, as organic material $>2000 \mu \mathrm{m}$ is not considered POM.

${ }^{2}$ This material was not fractionated but rather calculated by difference between total $\mathrm{C}$ content and $\mathrm{C}$ content of subfractions.
}

Fig. 1 Graphical representation of the two fractionation schemes used.

intra-POM material to measure. A $5 \mathrm{~g}$ subsample was suspended in $45 \mathrm{ml}$ of $1.85 \mathrm{~g} \mathrm{~cm}^{-3}$ sodium polytungstate. After centrifugation, the floating material (i.e. the free light POM) was aspirated. The heavy fraction was dispersed in $0.5 \%$ hexametaphosphate, and sieved through 2000, 250 and $53 \mu \mathrm{m}$ sieves, depending on the aggregate size being analyzed. The material remaining on the sieves was dried and weighed.
Fractionation scheme B: separation of total heavy and light POM and texture analysis

Total POM was separated by dispersing a $30 \mathrm{~g}$ subsample (see previous section) and sieving this through a $53 \mu \mathrm{m}$ sieve. From this material, the total light POM $\left(<1.85 \mathrm{~g} \mathrm{~cm}^{-3}\right)$ was separated by flotation as described in the previous section. The silt and clay that 
passed through the sieve were transferred to sedimentation cylinders and used to measure clay content using the hydrometer method. The amount of silt was calculated by difference.

\section{Carbon and nitrogen analysis}

Total $\mathrm{C}$ and nitrogen $(\mathrm{N})$ concentrations in aggregate fractions and intra-POM were measured with a LECO CHN-1000 analyzer (Leco Corp., St Joseph, MI, USA). When not enough material was available, samples were measured on an ANCA 20-20 GSL analyzer (PDZ Europe Ltd, Cheshire, UK), which requires less material for analysis. No carbonates were present. Total C and N concentrations of all fractions were normalized on a sand-free basis (Six et al., 1998). Weights of intra$\mathrm{POM}+$ sand were used to sand-correct aggregate $\mathrm{C}$ and intra-POM C contents (see fractionation scheme $\mathrm{A}$ in Fig. 1) and weights of total heavy POM + sand and total light $\mathrm{POM}+$ sand were used to correct $\mathrm{C}$ and $\mathrm{N}$ contents of total heavy POM, total light POM and total POM (see fractionation scheme B).

\section{Carbon accumulation rates}

The rate of $\mathrm{C}$ accumulation for all treatments was calculated by dividing the difference in soil $\mathrm{C}$ between each treatment (afforested and successional) and the control treatment (agricultural) by the duration of the experiment (Huntington, 1995; Van Laer et al., 1995). Two assumptions were made: (1) at the beginning of the experiment there was no difference in soil $\mathrm{C}$ between the afforested, successional and control treatments (the agricultural field) and (2) the C content of the agricultural field did not significantly change between 1989 and 1999 (Post \& Kwon, 2000). Assumption (1) is valid since $C$ values $(0-15 \mathrm{~cm})$ from the baseline sampling at the start of the experiment did not differ significantly: $\quad 9.04 \pm 0.84, \quad 8.64 \pm 0.9$ and $9.69 \pm$ $0.9 \mathrm{~g} \mathrm{C} \mathrm{kg}^{-1}$ for the agricultural, afforested and successional treatments, respectively (Kellogg biological station's long-term ecological research data catalog, Robertson \& Paul, 1996). Assumption (2) is harder to test since the baseline data were sampled at different depths than in this experiment $(0-15 \mathrm{~cm}$ instead of $0-7$ and $7-25 \mathrm{~cm}$ ). We estimated values for the $7-15 \mathrm{~cm}$ layer using second-order interpolation. Total C concentrations for the $0-15 \mathrm{~cm}$ layer could then be calculated by taking weighed averages for the $0-7$ and $7-15 \mathrm{~cm}$ layers. Since the estimate for $C$ in the $0-15 \mathrm{~cm}$ layer $(9.08 \pm 0.63)$ was almost identical to the value in 1989 (9.04 \pm 0.84$)$, assumption (2) also seems valid. Standard deviation for $\mathrm{C}$ accumulation rates was calculated by considering the accumulation rate as a contrast of two means from independent groups (Sahai \& Ageel, 2000). Group independency follows from the fact that the agricultural and afforested systems are on different plots. Significance was tested using the procedure outlined in Sahai \& Ageel (2000).

\section{Statistical analysis}

The data were analyzed as a complete randomized design using the SAS statistical package for analysis of variance ANOVA with the MIXED procedure (SAS/ STAT, SAS Institute, 2001). Treatment, size class and depth were considered as fixed effects whereas replicate was a random effect. Differences between means were tested with the Tukey procedure for multiple comparisons (DIFF option of the LSMEANS statement) and with Fisher's LSD test.

\section{Results}

\section{Whole-soil characteristics}

Differences in total organic $\mathrm{C}$ of the mineral soil among ecosystems increased in the order agricultural $<$ afforested $<$ successional $\ll$ native forest systems for the $0-7$ and $7-25 \mathrm{~cm}$ layers (Table 2). No significant differences were observed at a depth of $25-50 \mathrm{~cm}$. The native forest had less clay and lower bulk density compared with the systems at the main site. Whole-soil organic C at depth 0-25 cm (Table 3) followed the same trends as described for depth $0-7 \mathrm{~cm}$. At depth $0-50 \mathrm{~cm}$, the agricultural, afforested and successional systems did not differ, while the native forest was significantly greater. Organic C accumulation rates were significant for both the afforested and the successional systems at the $0-7 \mathrm{~cm}$ depth. At depths $0-25$ and $0-50 \mathrm{~cm}$, only the successional system had a significant increase in C (Table 3 ).

\section{MWD and aggregate size distribution}

The MWD was strongly influenced by cultivation (Fig. 2). At $0-7$ and $7-25 \mathrm{~cm}$ depths, the agricultural field had a significantly smaller MWD compared with the other systems. The non-cultivated systems were very similar at all depths. Differences in MWD were mainly due to differences in the large macroaggregate size class ( $>2000 \mu \mathrm{m}$ ) (Fig. 3). The cultivated system had a larger proportion of soil in the microaggregate size class (53$250 \mu \mathrm{m})$

\section{Aggregate carbon}

Aggregate $\mathrm{C}$ content of the mineral soil generally decreased in the following order: macroaggregate 
Table 2 Mineral soil organic carbon, texture (mean \pm standard error) and bulk densities at three soil depths (0-7, 7-25 and $25-50 \mathrm{~cm}$ ) of an agricultural, poplar afforested, successional and native forest system

\begin{tabular}{|c|c|c|c|c|c|c|}
\hline Depth $(\mathrm{cm})$ & Treatment & Organic $\mathrm{C}\left(\mathrm{gC} \mathrm{kg}^{-1}\right.$ soil $)$ & Clay $(\%)$ & Silt $(\%)$ & Sand $(\%)$ & Bulk density $\left(\mathrm{g} \mathrm{cm}^{-3}\right)$ \\
\hline \multirow[t]{4}{*}{$0-7$} & Agricultural & $10.0 \mathrm{C} \mathrm{a}$ & $26 \pm 6$ & $37 \pm 3$ & $37 \pm 4$ & $1.4 \mathrm{~A}$ \\
\hline & Afforested & $14.0 \mathrm{BC} \mathrm{a}$ & $24 \pm 5$ & $38 \pm 2$ & $38 \pm 4$ & $1.3 \mathrm{~A}$ \\
\hline & Successional & $16.0 \mathrm{~B} \mathrm{a}$ & $24 \pm 5$ & $39 \pm 2$ & $37 \pm 4$ & $1.4 \mathrm{~A}$ \\
\hline & Native forest & $29.3 \mathrm{~A} \mathrm{a}$ & 9 & 24 & 67 & $1.1 \mathrm{~B}$ \\
\hline \multirow[t]{4}{*}{$7-25$} & Agricultural & $8.5 \mathrm{BC} \mathrm{a}$ & $26 \pm 7$ & $39 \pm 6$ & $35 \pm 5$ & $1.5 \mathrm{~A}$ \\
\hline & Afforested & $7.9 \mathrm{C} \mathrm{b}$ & $26 \pm 6$ & $37 \pm 4$ & $37 \pm 2$ & $1.4 \mathrm{~A}$ \\
\hline & Successional & $9.9 \mathrm{AB} \mathrm{b}$ & $25 \pm 6$ & $40 \pm 5$ & $34 \pm 5$ & $1.4 \mathrm{~A}$ \\
\hline & Native forest & $11.1 \mathrm{~A} \mathrm{~b}$ & $21 \pm 9$ & $25 \pm 17$ & $54 \pm 26$ & $1.3 \mathrm{~B}$ \\
\hline \multirow[t]{4}{*}{$25-50$} & Agricultural & $3.7 \mathrm{~A} \mathrm{~b}$ & $26 \pm 6$ & $37 \pm 5$ & $37 \pm 3$ & $1.6 \mathrm{~A}$ \\
\hline & Afforested & $3.4 \mathrm{~A} \mathrm{C}$ & $28 \pm 2$ & $36 \pm 3$ & $36 \pm 1$ & $1.6 \mathrm{~A}$ \\
\hline & Successional & $3.6 \mathrm{~A} \mathrm{c}$ & $25 \pm 5$ & $38 \pm 3$ & $37 \pm 4$ & $1.6 \mathrm{~A}$ \\
\hline & Native forest & $3.5 \mathrm{~A} \mathrm{~b}$ & $18 \pm 8$ & $25 \pm 12$ & $57 \pm 19$ & $1.6 \mathrm{~A}$ \\
\hline
\end{tabular}

Within a depth, treatments followed by a different uppercase letter differ significantly among treatments $(P<0.05)$. Within a treatment, depths followed by a different lowercase letter differ significantly among depths $(P<0.05)$.

Table 3 Mineral soil organic carbon and organic carbon (OC) accumulation rate at three soil depths $(0-7,0-25,0-50 \mathrm{~cm})$ of an agricultural, poplar afforested, successional and native forest system

\begin{tabular}{llll}
\hline Depth $(\mathrm{cm})$ & Treatment & OC $\left(\mathrm{tCha}^{-1}\right)$ & OC accumulation rate $\left(\mathrm{tCha}^{-1} \mathrm{yr}^{-1}\right)$ \\
\hline $0-7$ & Agricultural & $9.4 \mathrm{D}$ & $\mathrm{NR}$ \\
& Afforested & $12.6 \mathrm{C}$ & $0.318^{*}$ \\
& Successional & $15.4 \mathrm{~B}$ & $0.596^{*}$ \\
& Native forest & $22.9 \mathrm{~A}$ & $\mathrm{NR}$ \\
$0-25$ & Agricultural & $31.9 \mathrm{C}$ & $\mathrm{NR}$ \\
& Afforested & $32.3 \mathrm{C}$ & 0.035 \\
& Successional & $40.0 \mathrm{~B}$ & $0.813^{*}$ \\
& Native forest & $48.6 \mathrm{~A}$ & $\mathrm{NR}$ \\
$0-50$ & Agricultural & $46.7 \mathrm{~B}$ & $\mathrm{NR}$ \\
& Afforested & $45.7 \mathrm{~B}$ & -0.107 \\
& Successional & $54.6 \mathrm{AB}$ & $0.786^{*}$ \\
& Native forest & $62.4 \mathrm{~A}$ & $\mathrm{NR}$ \\
\hline
\end{tabular}

NR, not relevant. Within a depth, treatments followed by a different uppercase letter differ significantly among treatments $(P<0.05)$. Accumulation rates followed by an asterisk $\left.{ }^{*}\right)$ are significant $(P<0.05)$.

$(>250 \mu \mathrm{m})$ associated $\mathrm{C}>$ microaggregate $(53-250 \mu \mathrm{m})$ associated $\mathrm{C}>\mathrm{C}$ associated with silt and clay particles $(<53 \mu \mathrm{m})$ (Fig. 4). Within a size class, aggregate C concentrations of the agricultural, afforested and successional systems were generally similar while aggregate $C$ in the native forest was significantly larger. Among systems, differences generally decreased with increasing depth. The largest differences in C among systems were found in the large macroaggregate fraction.

\section{Carbon content of intra-POM and free light POM (fractionation scheme $A$ )}

The mineral associated OM fraction accounts for most of the total $\mathrm{C}$ content and was largest in the native forest system (Fig. 5). The amount of $\mathrm{C}$ in the free light $\left(<1.85 \mathrm{~g} \mathrm{~cm}^{-3}\right)$ POM increased in the following order: agricultural $<$ afforested $\approx$ successional $<$ native forest systems. Total coarse $(>250 \mu \mathrm{m})$ intra-POM C and total fine $(53-250 \mu \mathrm{m})$ intra-POM $C$ of the native forest were significantly greater than in the other systems. No differences existed in total coarse intra-POM C among the agricultural, afforested and successional systems whereas the total fine intra-POM of the agricultural system was significantly less than in the afforested and successional systems. There was about half as much $\mathrm{C}$ in the free light, total fine and total coarse POM fractions at a depth of $7-25$ than at $0-7 \mathrm{~cm}$.

Figure 6 shows the $C$ concentrations in the separate intra-POM fractions of the separate aggregate size classes. For the afforested, native forest and successional 


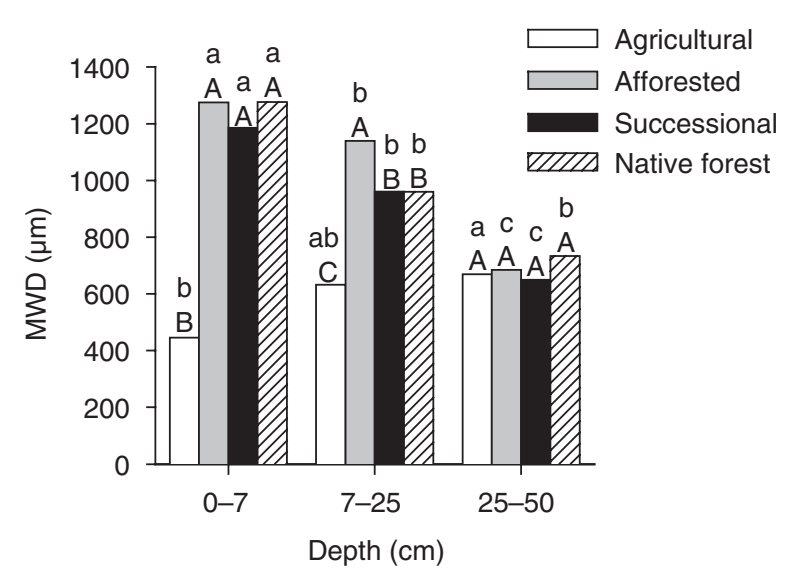

Fig. 2 Mean weight diameter (MWD) of slaked soils at three mineral soil depths $(0-7,7-25$ and $25-50 \mathrm{~cm})$ of an agricultural, poplar afforested, successional and native forest system. Within a treatment, bars with a different lowercase letter differ significantly among depths $(P<0.05)$. Within a depth, bars with a different uppercase letter differ significantly among treatments $(P<0.05)$.

systems, the greatest $\mathrm{C}$ concentration was observed in the intra-POM of the microaggregates $(53-250 \mu \mathrm{m})$ (53f in Figs 1 and 6). Fine intra-POM C concentration (2000f, 250f and 53 in Figs 1 and 6) was largest in the native forest and larger in the afforested than the agricultural field. Coarse intra-POM C concentration (2000c and 250c) was also largest in the native forest, but there were no differences among agricultural, afforested and successional systems. No significant differences existed among the intra-POM C concentrations of the agricultural, afforested and successional systems at a depth of $7-25 \mathrm{~cm}$.

For both the afforested and successional systems, there was significant $\mathrm{C}$ accumulation in all POM fractions and particularly in the fine intra-POM fraction (Table 4). Furthermore, the afforested system had a very significant increase in the coarse intra-POM fraction. The succession had a very significant $(P<0.01)$ increase in the mineral-associated OM. At a depth of $7-25 \mathrm{~cm}, \mathrm{C}$ accumulation rates were not significant.

\section{Carbon content of total, light and heavy POM (fractionation scheme $B$ )}

On average, total POM (see fractionation scheme B in Fig. 1) accounted for $\sim 28 \%$ of all $\mathrm{C}$ in the mineral surface soil $(0-7 \mathrm{~cm})$ and $\sim 17 \%$ at the $7-25 \mathrm{~cm}$ depth (Fig. 5). The native forest had more total heavy POM $\left(>1.85 \mathrm{~g} \mathrm{~cm}^{-3}\right)$ at the surface $(0-7 \mathrm{~cm})$ than the other systems. No significant differences in total heavy POM among systems were observed at depth $7-25 \mathrm{~cm}$. At the surface $(0-7 \mathrm{~cm})$, the agricultural system contained the least total light POM $\left(<1.85 \mathrm{~g} \mathrm{~cm}^{-3}\right)$. At $7-25 \mathrm{~cm}$, the native forest contained the most total light POM.

Figure 5 compares the two fractionation schemes. Ideally, total amounts of C (bar heights) and total amounts of POM should be the same. Because of the many steps of fractionation scheme A in comparison with fractionation scheme $\mathrm{B}$ and often the limited number of aggregates available, total POM in fractionation scheme A is generally smaller than total POM in fractionation scheme $\mathrm{B}$ and mineral associated $\mathrm{OM}$ in fractionation scheme $\mathrm{A}$ was greater than in fractionation scheme B (except for the native forest).

\section{Carbon to nitrogen ratios}

For almost all fractions, the native forest had the largest C-to- $\mathrm{N}$ ratios and the agricultural system had the smallest (Table 5). At the $7-25 \mathrm{~cm}$ depth, only the $\mathrm{C}-\mathrm{N}$ ratio of aggregate fractions and light POM $\left(<1.85 \mathrm{~g} \mathrm{~cm}^{-3}\right)$ differed among systems. At both soil depths, total soil $\mathrm{C}-\mathrm{N}$ ratios decreased significantly in the order: native forest $>$ successional $\approx$ afforested $>$ agricultural systems. While no clear differences in $\mathrm{C}-\mathrm{N}$ ratios of intra-POM size classes were observed, the total light POM fraction had significantly greater $\mathrm{C}-\mathrm{N}$ ratios compared with the total heavy POM fraction.

\section{Discussion}

\section{Carbon sequestration: rate and extent}

The experimental treatments represent possible landuse changes from conventional agriculture that can potentially lead to $C$ sequestration and a mitigation of greenhouse gas emissions. The natural succession treatment is representative of land abandonment and is similar to conservation set-asides such as in the Conservation Reserve Program. It has a typical perennial grass-dominated vegetation that established quickly. The poplar treatment is managed as a shortrotation biomass crop that could be used for energy production and/or as an industrial feedstock.

The difference in $\mathrm{C}$ content of the mineral soil between the native forest and the agricultural system serves as an indicator for the overall $C$ sequestration potential (Ellert \& Gregorich, 1996). Our data suggest that there is considerable potential for $\mathrm{C}$ sequestration in the surface layer $(0-7 \mathrm{~cm})$ of these soils. Cultivation reduced surface soil $(0-7 \mathrm{~cm}) \mathrm{C}$ by $60 \%$ compared with forest soils (Table 3). This is in agreement with other studies. Johnson \& Pfleger (1992) found soil C losses of 30-60\% (0-7 cm) and Ellert \& Gregorich (1996) found a $34 \%$ loss of C. However, sequestration potential decreases sharply with increasing depth. At a depth 

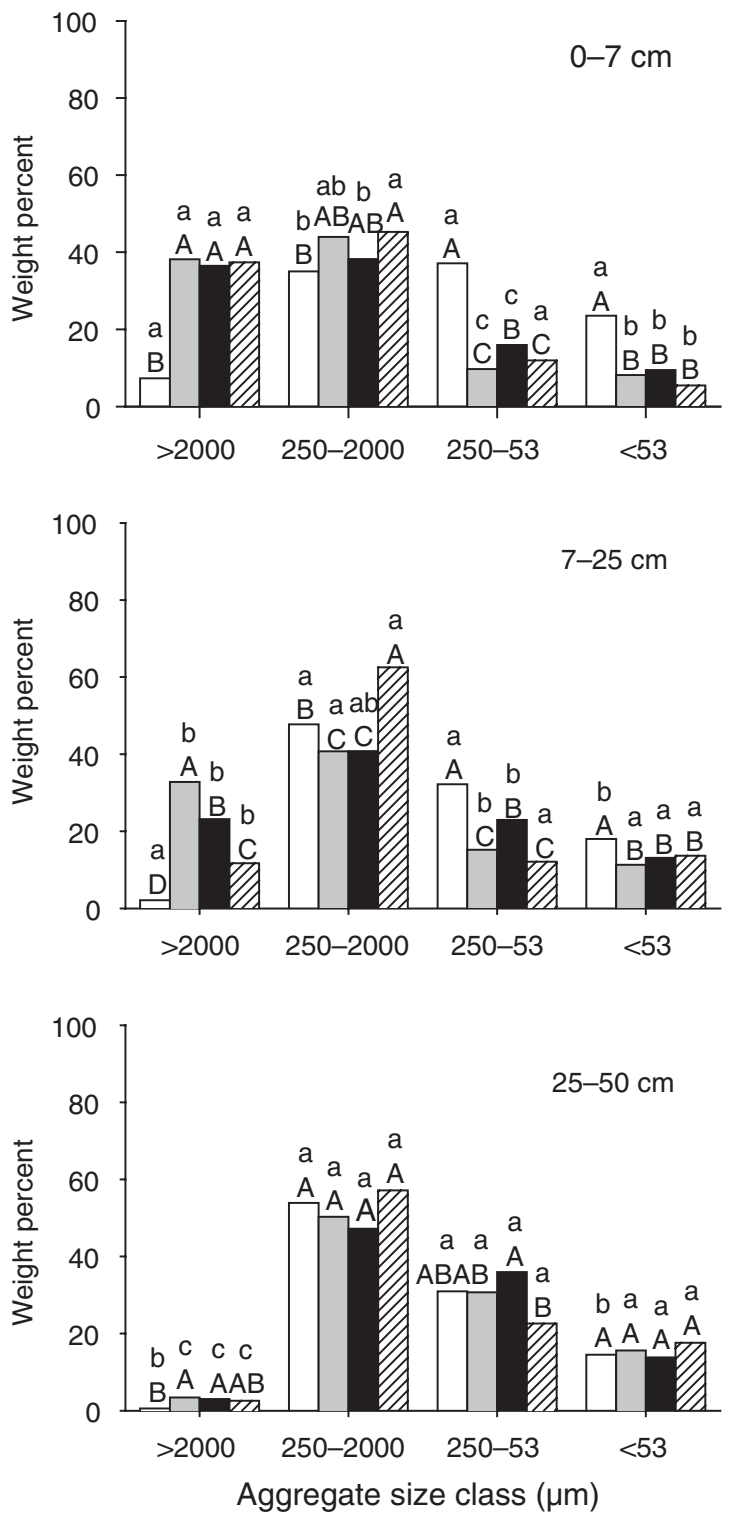

Fig. 3 Weight percentages of slaking resistant aggregates at three mineral soil depths $(0-7,7-25$ and $25-50 \mathrm{~cm})$ of an agricultural, poplar afforested, successional and native forest system. Within a treatment and an aggregate size class, bars with a different lowercase letter differ significantly among depths $(P<0.05)$. Within a depth and an aggregate size class, bars with a different uppercase letter differ significantly among treatments $(P<0.05)$.

of $7-25 \mathrm{~cm}$, inferred cultivation losses were only $10 \%$ and at a depth of $25-50 \mathrm{~cm} \mathrm{C}$ concentrations between native forest and the agricultural system were not significantly different (Table 2).

Differences in mineral soil $\mathrm{C}$ between the land-use change treatments and the agricultural system after 10 years of establishment serve as an indicator for $\mathrm{C}$ sequestration rates. Rates of $\mathrm{C}$ accumulation varied
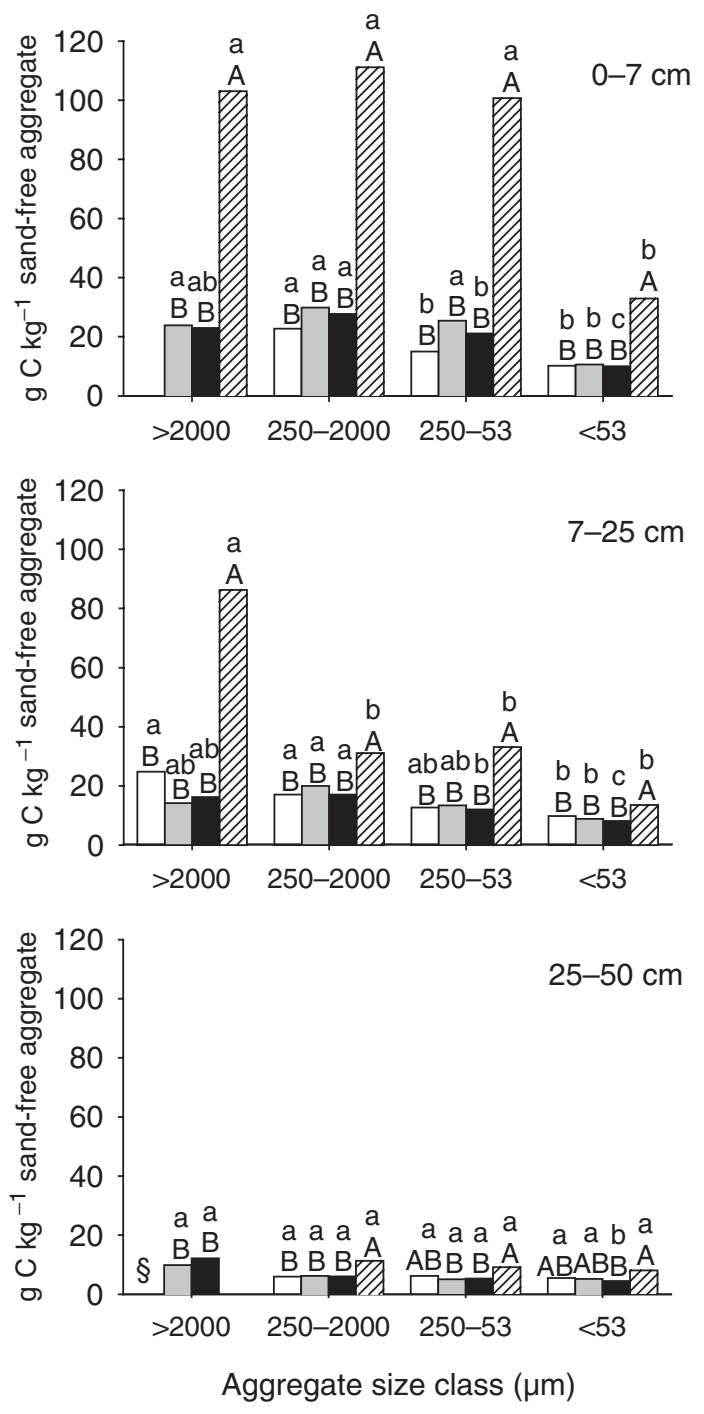

$\S$ Not enough material was available

Fig. 4 Total sand-corrected aggregate carbon at three mineral soil depths $(0-7,7-25$ and $25-50 \mathrm{~cm})$ of an agricultural, poplar afforested, successional and native forest system. Within a depth and treatment, bars with a different lowercase letter differ significantly among size classes $(P<0.05)$. Within a depth and size class, bars indicated by a different uppercase letter differ significantly among treatments $(P<0.05)$.

considerably between afforested and successional systems and among depths (Table 3). At the surface (0$7 \mathrm{~cm}$ ), cessation of cultivation and conversion to perennial vegetation increased total soil $\mathrm{C}$ in both treatments. Rates of $\mathrm{C}$ accumulation in the soil surface $(0-7 \mathrm{~cm})$ were comparable with the average accumulation rate of $0.30-0.50 \mathrm{tC} \mathrm{ha}^{-1} \mathrm{yr}^{-1}$ reported for afforested systems by Post \& Kwon (2000) and Six et al. (2002a).

Some authors have suggested that forest soils could sequester C in the subsoil (Huntington, 1995; Post \& 

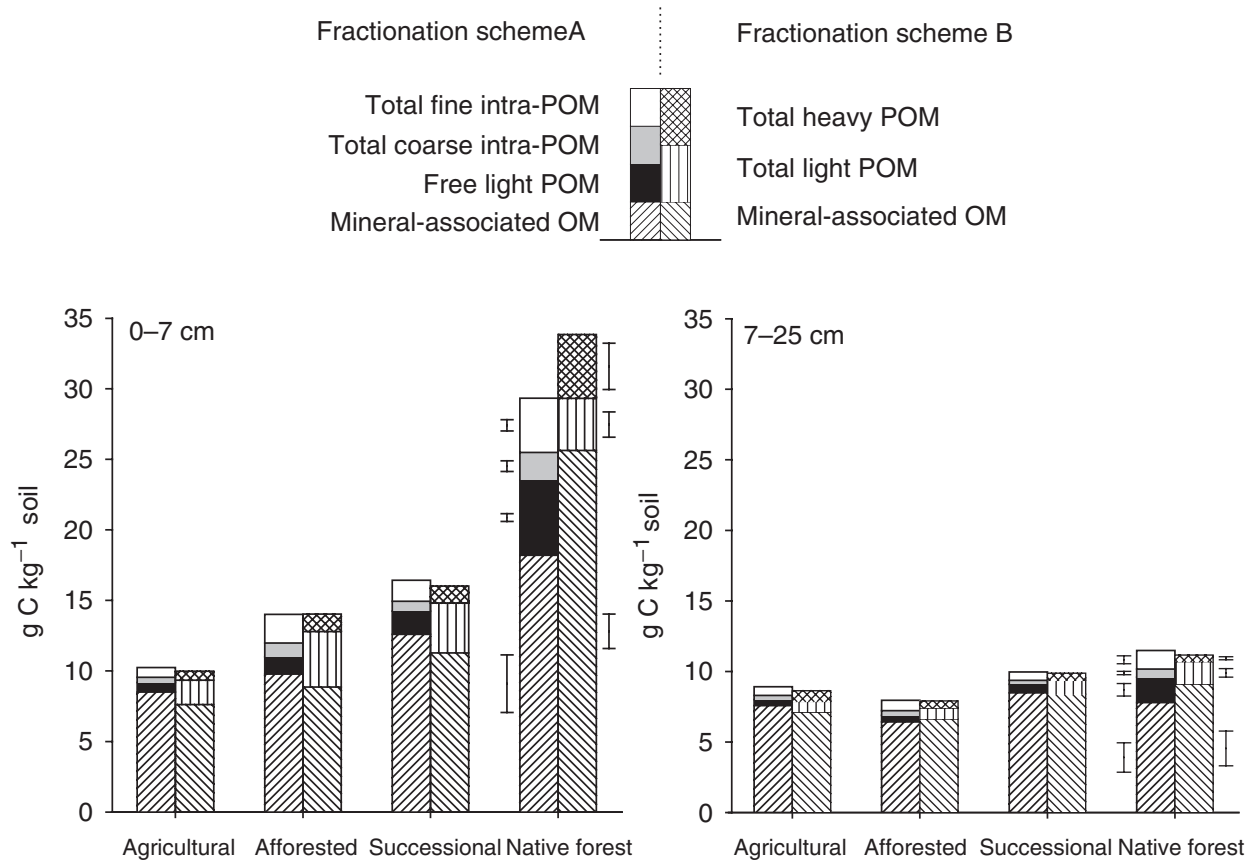

Fig. 5 Total carbon content divided into $C$ fractions at two mineral soil depths $(0-7$ and $7-25 \mathrm{~cm})$ of an agricultural, poplar afforested, successional and native forest system. See Fig. 1 for explanation of the fractions. Within a depth, treatment and fractionation scheme, error bars represent the Fisher's LSD $(P<0.05)$ among fractions.

Table 4 Carbon accumulation rates for four fractions at two mineral soil depths $(0-7,7-25 \mathrm{~cm})(\mathrm{means} \pm$ standard deviation) of a poplar afforested and a successional system

$\mathrm{C}$ accumulation rate $\left(\mathrm{tCha} \mathrm{hr}^{-1}\right)$

\begin{tabular}{llcccr}
\cline { 3 - 5 } Treatment & Depth $(\mathrm{cm})$ & Free light POM & Total fine intra-POM & Total coarse intra-POM & Mineral-associated OM \\
\hline Afforested & $0-7$ & $0.046 \pm 0.019^{*}$ & $0.117 \pm 0.020^{* *}$ & $0.054 \pm 0.014^{* *}$ & $0.087 \pm 0.105$ \\
& $7-25$ & $-0.008 \pm 0.015$ & $0.022 \pm 0.040$ & $0.005 \pm 0.018$ & $-0.412 \pm 0.215$ \\
Successional & $0-25$ & $0.038 \pm 0.027$ & $0.139 \pm 0.053^{*}$ & $0.059 \pm 0.028$ & $-0.325 \pm 0.298$ \\
& $0-7$ & $0.063 \pm 0.022^{*}$ & $0.075 \pm 0.026^{* *}$ & $0.031 \pm 0.011^{*}$ & $0.415 \pm 0.091$ \\
& $7-25$ & $0.035 \pm 0.017$ & $-0.013 \pm 0.022$ & $-0.008 \pm 0.015$ & $0.096 \pm 0.178$ \\
& $0-25$ & $0.098 \pm 0.023^{* *}$ & $0.062 \pm 0.046$ & $0.0023 \pm 0.024$ & $0.511 \pm 0.186^{*}$ \\
\hline
\end{tabular}

Free light particulate organic matter $(\mathrm{POM})$ is material $<1.85 \mathrm{~g} . \mathrm{cm}^{-3}$, total fine intra-POM $=$ total fine intra-aggregate POM $(53-$ $250 \mu \mathrm{m})$, total coarse intra-POM = total coarse intra-aggregate POM $(250-2000 \mu \mathrm{m})$ and mineral associated OM is material associated with the silt and clay fraction $(<53 \mu \mathrm{m})$. Accumulation rates significantly different from 0 are marked with ${ }^{*}$ for $P<0.05$ and ${ }^{* *}$ for $P<0.01$.

Kwon, 2000). The deep rooting system of trees and the mixing of soil horizons due to the uprooting of trees from events such as windthrow (Schaetzel, 1986) would supply a large amount of OM deep in the soil. Additionally, decomposition is believed to occur slower at depth (Cole et al., 1977). However, we found no indications that $\mathrm{C}$ accumulated at depth as $\mathrm{C}$ content in the afforested and successional systems were similar to those of the agricultural system $(7-25$ and $25-50 \mathrm{~cm}$ ). Many studies have reported no change or a decrease in subsurface soil $\mathrm{C}$ during the first years after afforesting.
Richter et al. (1999) found a decrease in soil C (35$60 \mathrm{~cm}) 40$ years after afforesting on a sandy loam soil. In addition, using ${ }^{14} \mathrm{C}$ techniques, these authors found evidence that the original crop roots decomposed quickly during the first stage of forest regrowth. Similarly, Binkley \& Resh (1999) found no net change of total subsoil C after conversion of sugarcane, Saccharum officinarum $\mathrm{L}$. to forest whereas ${ }^{13} \mathrm{C}$ measurements showed a fast replacement of the sugarcane $C$ with forest-derived C. When comparing 15 forest sites, Ellert \& Gregorich (1996) found that only four sites had 

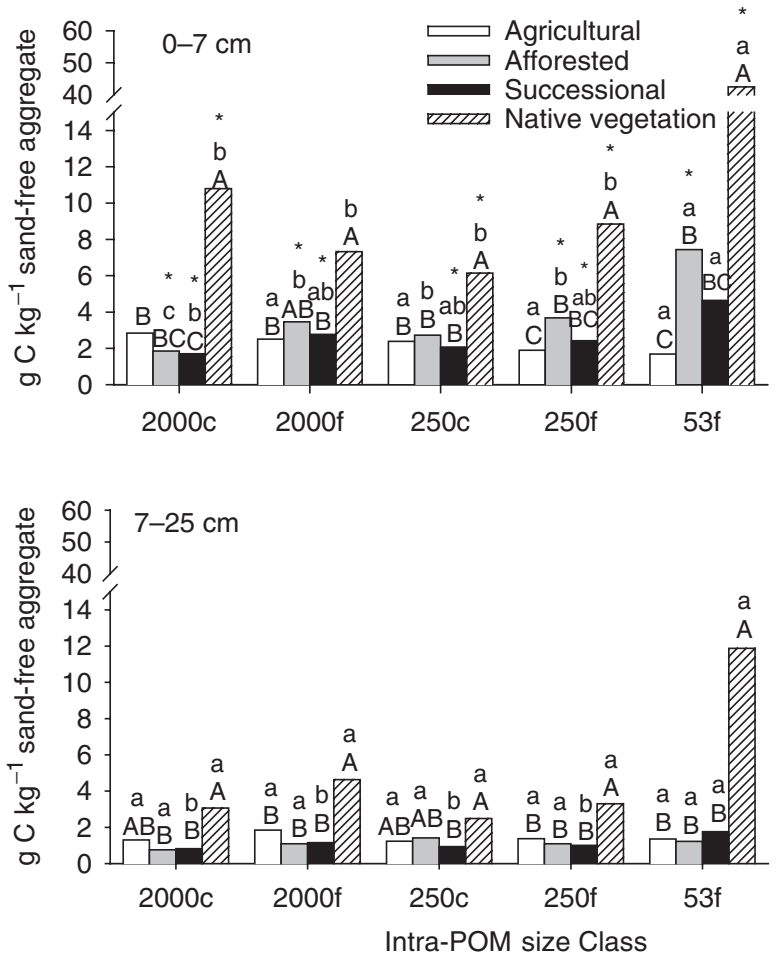

Fig. 6 Intra-aggregate POM (intra-POM) $\mathrm{C}$ at two mineral soil depths $(0-7$ and $7-25 \mathrm{~cm})$ of an agricultural, poplar afforested, successional and native forest system. $2000 \mathrm{c}=$ coarse intra-POM $(>250 \mu \mathrm{m})$ in the large macroaggregate fraction $(>2000 \mu \mathrm{m})$, $2000 \mathrm{f}=$ fine intra-POM $(53-250 \mu \mathrm{m})$ in the large macroaggregate fraction, $250 \mathrm{c}=$ coarse intra- $\mathrm{POM}$ in the small macroaggregate fraction $(250-2000 \mu \mathrm{m}), 250 \mathrm{f}=$ fine intra-POM in the small macroaggregate fraction $(250-2000 \mu \mathrm{m}), 53 \mathrm{f}=$ fine intra-POM $(53-250 \mu \mathrm{m})$ in the microaggregate fraction $(53-250 \mu \mathrm{m})$. Within a depth and intra-POM fraction, bars indicated by a different uppercase letter differ significantly among treatments $(P<0.05)$. Within a depth and treatment, bars indicated by a different lowercase letter differ significantly among intra-POM fraction $(P<0.05)$. Within a treatment and intra-POM fraction, bars with an asterisk differ significantly between the two depths $(P<0.05)$.

significantly higher $C$ in subsurface layers compared with cultivated areas. In contrast, Schiffman \& Johnson (1988) found no differences in total soil C among converted plantations, old field afforested sites, native forests and control fields. In a chronosequence study, Zak et al. (1990) found that rates of $C$ first declined for 10 years and then increased continuously over a 50 -year period. Thus, $10-40$ years may be necessary before an increase in subsurface soil $\mathrm{C}$ stocks of afforested systems becomes apparent.

It remains unclear how long $C$ will accumulate in an aggrading forest as the change in accumulation rates over time varies considerably among studies. Huntington (1995) found the highest rates of C accumulation from 30 to 110 years after afforesting and he proposed that $C$ increased sigmoidally over time. Similar results were obtained by Poulton et al. (2003). Post \& Kwon (2000), on the other hand, found that about half of the relevant studies in their review showed a significant slowing in the rate of $\mathrm{C}$ accumulation 50-100 years after afforesting.

\section{Aggregate and aggregate associated carbon regeneration}

It is generally assumed that SOM is protected in soil aggregates (e.g. Puget et al., 1995; Angers et al., 1997; Six et al., 1998). Therefore, the relationship between aggregate regeneration and soil $\mathrm{C}$ within the aggregates was investigated. At the soil surface $(0-7 \mathrm{~cm})$, regeneration of soil structure occurred quickly following cessation of cultivation and annual cropping (Figs 2 and 3). The afforested and successional treatments had equivalent aggregate distributions in comparison with the native vegetation levels. These results are in agreement with Jastrow (1996), who observed a similarly fast (10 years) regeneration of soil structure in a restored tallgrass prairie. In contrast to the fast regeneration of soil aggregate structure, aggregate $C$ did not follow this fast recovery (Fig. 4). This lag between soil structure reformation and $\mathrm{C}$ accumulation was also observed by Jastrow (1996), Angers (1992) and Six et al. (2002a). Although the mechanism of C protection inside aggregates is widely acknowledged, $\mathrm{C}$ sequestration by occlusion into aggregates appears to be a relatively slow phenomenon.

\section{Potential amount and rate of carbon sequestration among fractions}

Two different fractionation schemes were used to find fractions that are (1) $C$ enriched, thus forming a pool where $C$ is sequestered and (2) a sensitive indicator for the change in total $C$ after the possible land-use changes. For the first objective, the native vegetation data should be compared with the agricultural field, whereas the different land-use conversion systems should be compared with the agricultural field for the second objective. A complex and labor-intensive fractionation scheme (fractionation scheme A in Fig. 1) isolating small but potentially very sensitive $C$ pools is compared with a much simpler and probably lesssensitive fractionation scheme (fractionation scheme B). Both fractionation schemes distinguish between POM and mineral-associated $\mathrm{OM}<53 \mu \mathrm{m}$. Fractionation scheme A separates POM enclosed (intra-POM) and not enclosed (freelight POM) within different soil aggregate size classes. This fractionation further separates intra-POM according to size: fine intra-POM (53- 
Table 5 Carbon to nitrogen ratios of total mineral soil, aggregate size classes, intra-POM fractions and total POM fractions at two soil depths $(0-7$ and $7-25 \mathrm{~cm})$ of an agricultural, poplar afforested, successional and native forest system

\begin{tabular}{|c|c|c|c|c|c|c|c|c|c|}
\hline & & \multicolumn{4}{|l|}{$0-7 \mathrm{~cm}$} & \multicolumn{4}{|l|}{$7-25 \mathrm{~cm}$} \\
\hline & & Agricultural & Afforested & Successional & Native forest & Agricultural & Afforested & Successional & Native forest \\
\hline \multirow[t]{2}{*}{ Total soil } & & $10.6 \mathrm{C}$ & $12.6 \mathrm{~B}$ & $12.7 \mathrm{~B}$ & $14.5 \mathrm{~A}$ & $9.3 \mathrm{C}$ & $9.4 \mathrm{C}$ & $9.9 \mathrm{~B}$ & $12.1 \mathrm{~A}$ \\
\hline & $>2000$ & $\mathrm{NA}^{*}$ & $11.6 \mathrm{Ba}$ & $9.8 \mathrm{C} \mathrm{a}$ & $14.6 \mathrm{~A} \mathrm{a}$ & $10.1 \mathrm{~B} \mathrm{a}$ & $10.2 \mathrm{~B} \mathrm{a}$ & $9.8 \mathrm{~B} \mathrm{a}$ & $16.4 \mathrm{~A} \mathrm{a}$ \\
\hline \multirow{3}{*}{$\begin{array}{l}\text { Aggregate } \\
\text { size classes }\end{array}$} & $2000-250$ & $9.5 \mathrm{~B} \mathrm{a}$ & $11.8 \mathrm{AB}$ a & $10.5 \mathrm{AB}$ a & $12.9 \mathrm{~A} \mathrm{~b}$ & $8.2 \mathrm{C} \mathrm{ab}$ & $10 \mathrm{BC} \mathrm{a}$ & $9.4 \mathrm{~B} \mathrm{a}$ & $14.3 \mathrm{~A} \mathrm{ab}$ \\
\hline & $250-53$ & $9.2 \mathrm{C} \mathrm{ab}$ & $10.9 \mathrm{AB}$ a & $9.7 \mathrm{BC}$ a & $12.4 \mathrm{~A} \mathrm{bc}$ & $8.5 \mathrm{~B} \mathrm{ab}$ & $9.3 \mathrm{~B} \mathrm{a}$ & $9.4 \mathrm{~B} \mathrm{a}$ & $13.2 \mathrm{~A} \mathrm{ab}$ \\
\hline & $0-53$ & $8.3 \mathrm{~B} \mathrm{~b}$ & $8.5 \mathrm{~B} \mathrm{~b}$ & $7.7 \mathrm{~B} \mathrm{~b}$ & $10.8 \mathrm{~A} \mathrm{c}$ & $7.1 \mathrm{~B} \mathrm{~b}$ & $8 \mathrm{~B} \mathrm{~b}$ & $8.1 \mathrm{~B} \mathrm{~b}$ & $10.3 \mathrm{~A} \mathrm{~b}$ \\
\hline \multirow{5}{*}{$\begin{array}{r}\text { Intra-POM } \\
\text { fractions }\end{array}$} & $2000 c$ & $11.3 \mathrm{~B} \mathrm{a}$ & $13.6 \mathrm{AB}$ a & $12 \mathrm{~B}$ a & $16.1 \mathrm{~A} \mathrm{a}$ & $9.7 \mathrm{~A} \mathrm{a}$ & $10.9 \mathrm{~A} \mathrm{a}$ & $8.9 \mathrm{~A} \mathrm{~b}$ & $8.4 \mathrm{~A} \mathrm{bc}$ \\
\hline & $2000 \mathrm{f}$ & $12.2 \mathrm{~A} \mathrm{a}$ & $14.1 \mathrm{~A} \mathrm{a}$ & $12.4 \mathrm{~A} \mathrm{a}$ & $12.9 \mathrm{~A} \mathrm{a}$ & $11.8 \mathrm{~A} \mathrm{a}$ & $12.2 \mathrm{~A} \mathrm{a}$ & $11 \mathrm{~A} \mathrm{a}$ & $12.6 \mathrm{~A} \mathrm{a}$ \\
\hline & $250 c$ & $8.6 \mathrm{~A} \mathrm{a}$ & $11.3 \mathrm{~A} \mathrm{a}$ & $9.8 \mathrm{~A} \mathrm{~b}$ & $11.4 \mathrm{~A} \mathrm{a}$ & $8.7 \mathrm{~A} \mathrm{a}$ & $7.7 \mathrm{~A} \mathrm{a}$ & $6.1 \mathrm{~A} \mathrm{C}$ & $6.4 \mathrm{~A} \mathrm{c}$ \\
\hline & $250 \mathrm{f}$ & $10.1 \mathrm{~B} \mathrm{a}$ & $14.5 \mathrm{~A} \mathrm{a}$ & $11.5 \mathrm{AB} b$ & $13.2 \mathrm{AB}$ a & $10.9 \mathrm{~A} \mathrm{a}$ & $12.2 \mathrm{~A} \mathrm{a}$ & $11 \mathrm{~A} \mathrm{a}$ & $9.9 \mathrm{~A} \mathrm{ab}$ \\
\hline & 53 & $10.7 \mathrm{~B} \mathrm{a}$ & $12.5 \mathrm{AB}$ a & $13.3 \mathrm{AB}$ a & $14.1 \mathrm{~A} \mathrm{a}$ & $11.2 \mathrm{~A} \mathrm{a}$ & $11.1 \mathrm{~A} \mathrm{a}$ & $9.1 \mathrm{~A} \mathrm{~b}$ & $12.3 \mathrm{~A} \mathrm{a}$ \\
\hline \multirow{2}{*}{$\begin{array}{r}\text { Total POM } \\
\text { fractions }\end{array}$} & HPOM & $9 \mathrm{~B} \mathrm{~b}$ & $9.3 \mathrm{~B} \mathrm{~b}$ & $9 \mathrm{~B} \mathrm{~b}$ & $12.9 \mathrm{~A} \mathrm{~b}$ & $11 \mathrm{~A} \mathrm{~b}$ & $9 \mathrm{~A} \mathrm{~b}$ & NA & NA \\
\hline & LPOM & $22.6 \mathrm{AB}$ a & $22.3 \mathrm{AB}$ & $21 \mathrm{~B} \mathrm{a}$ & $27.5 \mathrm{~A} \mathrm{a}$ & $22.4 \mathrm{~B} \mathrm{a}$ & $25.2 \mathrm{~B} \mathrm{a}$ & $22.1 \mathrm{~B} \mathrm{a}$ & $36.2 \mathrm{~A} \mathrm{a}$ \\
\hline
\end{tabular}

NA, not enough material available. Within a depth and size class, treatments followed by a different uppercase letter differ significantly $(P<0.05)$ among treatments. Within a depth and treatment, size classes followed by a different lowercase letter differ significantly $(P<0.05)$ among size classes.

POM, particulate organic matter; HPOM, total heavy POM; LPOM, total light POM.

$250 \mu \mathrm{m})$, mostly stabilized within microaggregates, vs. coarse intra-POM $(250-2000 \mu \mathrm{m})$ occluded within macroaggregates. Fractionation scheme $\mathrm{B}$ is much simpler and divides POM in two fractions according to its density: the total light POM has a density $<1.85 \mathrm{~g} \mathrm{~cm}^{-3}$ and the total heavy POM has a density $>1.85 \mathrm{~g} \mathrm{~cm}^{-3}$. Light total POM is thought to be younger and more plant derived, while total heavy POM is older and more microbially derived (Six et al., 2002b).

Of all fractions, the mineral associated $\mathrm{OM}$ fraction contains the most $C$ (Fig. 5). Although the native vegetation has much less silt and clay compared with the other treatments, amounts of mineral-associated C in the native forest were still similar to the afforested and successional systems. As a consequence, the relative concentration of $\mathrm{C}$ in the silt and clay fraction was six times larger in the native forest soils than in the soils of the other treatments. Therefore, the (high-clay) successional and afforested systems have a greater (absolute) potential for $\mathrm{C}$ accumulation within the mineral-associated $\mathrm{OM}$ fraction compared with the (low clay) native forest soil. Particulate OM makes up $17 \%$ of total $\mathrm{C}$ for the agricultural, $30 \%$ for the afforested, $23 \%$ for the successional and $38 \%$ for the native forest systems. These values are in agreement with literature data. Marquez et al. (1999) found that POM comprised $18-24 \%$ of total soil $\mathrm{C}$ in a riparian buffer planted with poplar after 10 years. Cromack et al. (1999) found that total light POM fraction could constitute as much as $40 \%$ of total C and N capital following afforesting.
When comparing the agricultural and native forest systems, $\mathrm{C}$ accumulation potential in the surface layer $(0-7 \mathrm{~cm}$ layer $)$ was largest in the mineral-associated $\mathrm{OM}$, the total fine intra-POM and free light POM fractions of fractionation scheme $\mathrm{A}$ and mineralassociated $\mathrm{OM}$ and total heavy POM fractions of fractionation scheme B (see Figs 1 and 5). The most sensitive fractions in $\mathrm{C}$ changes were the total fine intraPOM and free light POM $\left(<1.85 \mathrm{~g} \mathrm{~cm}^{-3}\right)$ in the afforested system, and the mineral-associated OM fraction in the successional system (Fig. 1 and Table 4). The difference in location of $\mathrm{C}$ accumulation between the afforested and successional systems indicates that ecosystem-specific factors play a role in this process.

The free light POM fraction as an unprotected $C$ pool seems to be consistently a sensitive indicator for ecosystem change. After the conversion of a native forest to corn, a substantial decline in free light POM C and $\mathrm{N}$ was observed by Besnard et al. (1996). Likewise, Arrouays \& Pelissier (1994) found that the rapid decrease in $\mathrm{C}$ during the first years after clearcutting was related to a decrease in free light POM.

Fractionation schemes A and B are complementary approaches. Fractionation scheme A focuses on mechanistic fractions, but tends to underestimate total POM, due to the many experimental steps. Fractionation scheme $B$ increases the sensitivity of $C$ measurements in comparison with a total $\mathrm{C}$ analysis. It gives a strong indication of the total amount of POM C that was sequestered in forest soils. 


\section{Mechanism of carbon accumulation}

Three general mechanisms are hypothesized to be important for $\mathrm{C}$ sequestration in a mineral soil: (1) increased plant net primary production and hence a higher C input in the soil, (2) higher litter recalcitrance and/or less favorable decomposition conditions and (3) enhanced physical or physicochemical protection of decomposition products.

The afforested system produces about as much aboveground biomass as the agricultural system but about twice as much as the succession. Still, differences in total $\mathrm{C}$ between the successional and afforested systems were small. Although no data were available to rigorously compare belowground production, these data already indicate that aboveground primary production changes are not the main factor in soil $\mathrm{C}$ accumulation in poplar afforested systems. The $\mathrm{C}$ contents associated with free light POM and coarse intra-POM are considered to be mostly determined by $\mathrm{C}$ input levels (Six et al., 1998). Therefore, the larger amount of C in the coarse intra-POM $(>250 \mu \mathrm{m})$ and free light POM $\left(<1.85 \mathrm{~g} \mathrm{~cm}^{-3}\right)$ fractions of the native forest compared with the other treatments may reflect a larger input of $C$ in the native forest compared with the other treatments. This is also supported by the greater amount of total light POM in the native forest than in the other systems. However, the greater C-to- $\mathrm{N}$ ratio of the native forest fractions, especially the unprotected fractions, could also be an indication of higher litter recalcitrance.

The consistent increase of $\mathrm{C}$ in the microaggregate $(53-250 \mu \mathrm{m})$ intra-POM fraction in both land-use change treatments compared with the agricultural system (Figs 5 and 6), corresponds with the suggestion that this fraction can serve as an early indicator of $\mathrm{C}$ accumulation in afforested systems (Six et al., 2002a). It also corroborates the hypothesis that microaggregates physically protect particulate C (Six et al., 1998, 2002a). The large $C$ enrichment of the free microaggregate intra-POM fraction (53f in Figs 1 and 6) is in accordance with studies by Skjemstad et al. (1990), Balesdent et al. (2000), and Bossuyt et al. (2002) highlighting the importance of free microaggregates for $\mathrm{C}$ sequestration. In contrast, the coarse intra-POM fractions (2000c and 250c in Figs 1 and 6) of the land-use change treatments are much more similar to the agricultural system, signifying the relatively low degree of protection exerted by macroaggregates alone (Six et al., 2002b).

\section{Conclusions}

- Most of the carbon changes occurred in the top soil layer $(0-7 \mathrm{~cm})$. Whereas soil carbon $(0-50 \mathrm{~cm})$ did not change significantly after poplar afforesting, it increased in the successional system at a rate of $0.8 \mathrm{tC} \mathrm{ha}^{-1}$. It was hypothesized that $10-40$ years may be necessary before an increase in subsurface soil carbon stocks of afforested systems becomes apparent.

- In all soils studied, most of the carbon was minerally associated. Fractionation indicated that microaggregates $(53-250 \mu \mathrm{m})$ stabilize POM. The POM ( $>53 \mu \mathrm{m})$ fraction enclosed within microaggregates served as an early indicator for total carbon changes. The increase in POM after land-use change occurred mainly in the heavy fraction (density $>1.85 \mathrm{~g} \mathrm{~cm}^{-3}$ ).

- After poplar afforesting, the largest accumulation of carbon occurred as POM $(53-250 \mu \mathrm{m})$ within soil, whereas the successional system accumulated carbon mainly as mineral-associated organic matter $(<53 \mu \mathrm{m})$.

- The results indicate that agricultural lands have greater potential for $\mathrm{C}$ sequestration than comparison with adjacent uncultivated sites would indicate.

\section{Acknowledgements}

This research was supported by US Department of Energy grants: Soil Organic Matter Dynamics and Management: Decision Making in an Enriched $\mathrm{CO}_{2}$ Environment (DE-FG0294ER61924) and Soil Carbon Saturation: Determining Limits on Carbon Sequestration Capacity (DE-FG03-00ER62997). The LTER site at Kellogg Biological Station is supported by the National Science Foundation under grant DEB98-10220. Steven De Gryze acknowledges a grant from the Fund for Scientific Research (FWO), Flanders, Belgium. Thanks to Kristin Coorevits for laboratory assistance.

\section{References}

Amthor JS (1998) Terrestrial ecosystem responses to global change. A research strategy. ORNL Technical Memorandum 27, National Laboratory, Oak Ridge, Tennessee..

Angers DA (1992) Changes in soil aggregation and organic carbon under corn and alfalfa. Soil Science Society of America Journal, 56, 1244-1249.

Angers DA, Recous S, Aita C (1997) Fate of carbon and nitrogen in water-stable aggregates during decomposition of ${ }^{13} \mathrm{C}{ }^{15} \mathrm{~N}$ labeled wheat straw in situ. European Journal of Soil Science, 48, 295-300.

Arrouays D, Pelissier P (1994) Changes in carbon storage in temperate humic loamy soils after forest clearing and continuous corn cropping in France. Plant and Soil, 160, 215223.

Balesdent J, Chenu C, Balabane M (2000) Relationship of soil organic matter dynamics to physical protection and tillage. Soil and Tillage Research, 53, 215-230.

Besnard E, Chenu C, Balesdent J et al. (1996) Fate of particulate organic matter in soil aggregates during cultivation. European Journal of Soil Science, 47, 495-503. 
Binkley D, Resh SC (1999) Rapid changes in soils following Eucalyptus afforestation in Hawaii. Soil Science Society of America Journal, 63, 222-225.

Bossuyt H, Six J, Hendrix P (2002) Aggregate protected carbon in no-tillage and conventional tillage agroecosystems using ${ }^{14} \mathrm{C}$ labeled plant residue. Soil Science Society of America Journal, 66, 1965-1973.

Cole VC, Innis GS, Stewart JWB (1977) Simulation of phosphorus cycling in semiarid grasslands. Ecology, 58, 1-15.

Cromack K Jr, Miller RE, Helgerson OT et al. (1999) Soil carbon and nutrients in a coastal Oregon Douglas-Fir plantation with Red Alder. Soil Science Society of America Journal, 63, 232-239.

Crum JR, Collins HP (1992) Kellogg biological station soil characterization. http://lter.kbs.msu.edu/Soil/characterization/

Del Galdo I, Six J, Peressotti A et al. (2003) Assessing the impact of land-use change on soil $\mathrm{C}$ sequestration in agricultural soils by means of organic matter fractionation and stable $\mathrm{C}$ isotopes. Global Change Biology, 9, 1204-1213.

Ellert B, Gregorich EG (1996) Storage of carbon, nitrogen and phosphorus in cultivated and adjacent forest soils of Ontario. Soil Science, 1619, 587-603.

Elliott ET (1986) Aggregate structure and carbon, nitrogen, and phosphorus in native and cultivated soils. Soil Science Society of America Journal, 50, 627-633.

Hassink J (1996) Preservation of plant residues in soils differing in unsaturated protective capacity. Soil Science Society of America Journal, 60, 487-491.

Huntington TG (1995) Carbon sequestration in an aggrading forest ecosystem in the SE USA. Soil Science Society of America Journal, 59, 1459-1467.

Jarrell WM, Armstrong DE, Grigal DF et al. (1999) Soil water and temperature status. In: Standard Soil Methods for Long-term Ecological Research (eds Robertson GP), pp. 55-73. Oxford University Press, Oxford, UK.

Jastrow JD (1996) Soil aggregate formation and the accrual of particulate and mineral-associated organic matter. Soil Biology and Biochemistry, 28, 665-676.

Jenkinson DS (1971) The accumulation of organic matter in soil left uncultivated. Report of the Rothamsted Experimental Station 1970, Part 2, pp. 113-137.

Johnson NC, Pfleger FL (1992) Vesicular-arbuscular mycorrhizae and cultural stresses. In: Mycorrhizae in Sustainable Agriculture (eds Bethlenfalvay GJ, Linderman RG), pp. 71-99. Soil Science Society of America, Madison.

Johnson WC, Sharpe DM (1983) The ratio of total merchantable forest biomass and its application to the global carbon budget. Canadian Journal for Forest Research, 13, 372-383.

Marquez CO, Cambardella CA, Isenhart TM et al. (1999) Assessing soil quality in a riparian buffer by testing organic matter fractions in central Iowa, USA. Agroforestry Systems, 44, 130-140.

Paustian K, Six J, Elliott ET et al. (2000) Management options for reducing $\mathrm{CO}_{2}$ emissions from agricultural soils. Biogeochemistry, 48, 147-163.

Post WM, Emanuel WR, Zinke PJ et al. (1982) Soil carbon pools and world life zones. Nature, 298, 156-159.

Post WM, Kwon KC (2000) Soil carbon sequestration and landuse change: processes and potential. Global Change Biology, 6, 317-327.
Poulton PR, Pye E, Hargreaves R et al. (2003) Accumulation of carbon and nitrogen by old arable land reverting to woodland. Global Change Biology, 9, 942-955.

Puget P, Chenu C, Balesdent J (1995) Total and young organic matter distributions in aggregates of silty cultivated soils. European Journal of Soil Science, 46, 449-459.

Richter DD, Markewitz D, Trumbore SE et al. (1999) Rapid accumulation and turnover of soil carbon in a re-establishing forest. Nature, 400, 56-58.

Robertson GP, Vitousek PM (1981) Nitrification potentials in primary and secondary succession. Ecology, 62, 376-386.

Robertson GP, Paul EA (1996) Kellogg biological station's longterm ecological research data catalog. http://lter.kbs.msu. edu/Data/DataCatalog.html.

Robertson GP, Paul EA, Harwood RR (2000) Greenhouse gases in intensive agriculture: contributions of individual gases to the radiative forcing of the atmosphere. Science, 289, 19221925.

Rollinger JL, Strong TF, Grigal DF (1997) Forested soil carbon storage in landscapes of the Northeren great lakes region. In: Management of Carbon Sequestration in Soil (eds Lal R, Kimble JM, Follett RF, Stewart BA), pp. 335-350. CRC Press, New York.

Sahai H, Ageel MI (2000) The Analysis of Variance. Fixed, Random, and Mixed Models. Birkhäuser Verlag, Boston.

Schaetzel RJ (1986) Complete soil profile inversion by tree uprooting. Physical Geography, 7, 181-188.

Schiffman PM, Johnson WC (1988) Phytomass and detrial carbon storage during forest regrowth in the southeastern United States Piedmont. Canadian Journal of Forest Research, 19, 69-76.

Schimel DS, House JI, Hibbard KA et al. (2001) Recent patterns and mechanisms of carbon exchange by terrestrial ecosystems. Nature, 414, 169-172.

Schindler DW (1999) The mysterious missing sink. Nature, 398, 105-106.

Six J, Callewaert P, Lenders S (2002a) Measuring and understanding carbon storage in afforested soils by physical fractionation. Soil Science Society of America Journal, 66, 19811987.

Six J, Conant RT, Paul EA et al. (2002b) Stabilization mechanisms of soil organic matter: implications for C-saturation of soils. Plant and Soil, 241, 155-176.

Six J, Elliott ET, Paustian K et al. (1998) Aggregation and soil organic matter accumulation in cultivated and native grassland soils. Soil Science Society of America Journal, 62, 1367-1377.

Skjemstad JO, Le Feuvre RP, Prebble RE (1990) Turnover of soil organic matter under pasture as determined by ${ }^{13} \mathrm{C}$ natural abundance. Australian Journal of Soil Research, 28, 267-276.

Van Laer DH, Kapeluck PR, Parker MM (1995) Distribution of carbon in a Piedmont soil as affected by loblolly pine management. In: Carbon Forms and Functions in Forest Soils (eds McFee WW, Kelly JM), pp. 489-501. Proceedings of the North American Forest Soils Conference, Gainesville, FL.

Zak DR, Grigal DF, Gleeson S et al. (1990) Carbon and nitrogen cycling during old field succession: constraints on plant microbial biomass. Biogeochemistry, 11, 111-129. 